\title{
外来血液透析患者の疲労感と種々の要因
}

\author{
中原宣子 ${ }^{1}$ 西口和美1 泉 暢 英 ${ }^{1}$ 鶴 崎 清 $之^{1}$ \\ 楠本 裕美 ${ }^{2}$ 荒川昌洋 ${ }^{2}$ 藤原 功 - 2 \\ 1公益財団法人浅香山病院 2特定医療法人紀陽会田仲北野田病院
}

キーワード：疲労感, 栄養, 日常活動量, 透析看護

〈要旨〉

透析患者の疲労は生命の質 $(\mathrm{QOL})$ の低下を招くばかりではなく種々の疾患の予兆, 特に心血管障害発症の強い危 険因子であるといわれている. 今回, 2 施設の通院血液透析患者 287 名を対象に疲労感についての共同調查研究を 行った. 本研究では透析患者の透析日の疲労は非透析日に比し有意に高く, 透析間体重増加量が多い $(\Delta \% B W>$ $8.0 \%$ ）場合疲労感が強かった. 疲労感は年齢よりも透析歴に相関し, 栄養状態の指標である血清 Alb 值が低い患者 ほど透析日, 非透析日ともに疲労感が強く負の相関を示した。 また, 毎日 30 分以上歩行している患者は疲労感が低 いことが示された，以上より, 透析患者の QOL を維持・向上させるには合併症治療とともに, 栄養状態の維持改 善と日常の中での活動能力の向上を推し進めていく支援の重要性が確認された.

\section{Fatigue and associated factors in maintenance hemodialysis patients}

Noriko Nakahara ${ }^{1}$, Kazumi Nishiguchi ${ }^{1}$, Nobuhide Izumi ${ }^{1}$, Kiyoshi Tsurusaki ${ }^{1}$, Hiromi Kusumoto ${ }^{2}$, Masahiro Arakawa², Kouichi Fujiwara²

${ }^{1}$ Asakayama General Hospital; ${ }^{2}$ Tanaka-kitanoda Hospital

Keywords: fatigue, nutrition, physical activity, nursing care

$\langle$ Abstract〉

In hemodialysis patients, fatigue, especially chronic fatigue, impairs quality of life (QOL) and is a risk factor for various diseases, especially cardiovascular diseases. We performed a co-operative study of fatigue, involving 287 maintenance hemodialysis patients that were being treated at the dialysis centers of two hospitals. This study showed that fatigue in hemodialysis patients was more severe on dialysis days than on non-dialysis days, and it was also more severe when the delta\% change in interdialytic body weight gain was $>8 \%$. Fatigue was correlated with the dialysis period, but not age. Fatigue was inversely correlated with the serum albumin level, which is a predictor of nutritional status, on both dialysis and non-dialysis days. In addition, patients who walked at least 30 minutes every day as physical exercise felt less fatigue. It was demonstrated that improving and maintaining nutritional status as well as promoting daily activity are important for maintaining and improving QOL among hemodialysis patients.

\section{緒言}

透析患者数の増加速度は緩やかになったとはいえ増 え続けており，また長期透析や高齢化が指摘されて久 しい，透析患者に対する看護のあり方も，適切な透析 技術の提供とともに，七ルフケアなどにより残る人生
に対して透析合併症の進展を防ぎ，安定した生活が送 れるように支援してきた。一方で, 終末期の透析やケ アのあり方を再考する機会も増えている．患者が抱え る問題は重症合併症も存在するが, 生活に即した身体 問題であることが多くみられるようになった。その中 で「疲労感」の訴えはさほどないものの, じっくり患 者と向き合うとよく聞かれる患者の悩みである。しか

中原 宣子 公益財団法人浅香山病院 † 590-0018 大阪府堺市堺区今池町 3-3-16

Noriko Nakahara Tel: 072-229-4882 Fax：072-229-7691

〔受付日：2018 年 11 月 5 日, 受理日：2019 年 6 月 10 日〕 
し，疲労感に関する看護研究はほとんど見当たらず, カルニチンとの関連についての学会/研究会報告が複 数件みられるが看護論文は見当たらない，看護論文で は幸福感に関連する要因として疲労感を指摘してい る ${ }^{1)}$ もや，運動療法との関連を指摘している がみられるが, 疲労感と透析との直接的な関連を検討 したものは見当たらない.

疲労感そのものは特に治療に至ることは少ない。し かし，身体に潜む問題を表出する契機，つまり，疾患 の悪化, 新たな合併症の発症・進展の危険因子であり, quality of life（QOL）にも大きな影響を与えると考え られている ${ }^{3,4)}$.

疲労とは「過度の肉体的および精神的活動，または 疾病によって生じた独特の不快感と休養の願望を伴う 身体の活動能力の減退状態」と定義されている。 さら に,「疲労」と「疲労感」の区別に対しても言及されて おり，「疲労」は心身への過負荷により生じた活動能力 の低下をいい,「疲労感」は疲労が存在することを自覚 する感覚で, 多くの場合不快感と活動意欲の低下が認 められる5) とされている。しかし, 疲労の他覚的評価 は難しい。渡辺らは疲労についての定性・定量的評価 法を開発し, 疲労についての研究を進め, その信頼 性・有用性を立証してきた ${ }^{34,6,7)}$ ．今回，64 項目ある問 診スケールのうち疲労感についての 8 項目を選び, 聞 き取り調査を行った。そして, 種々の要因との関連を 分析し疲労防止のための患者ケアに活かすことを試み た.

\section{I．対象および方法}

2017 年 7 月より透析施設 2 施設において, 強度の認 知障害を有し設問を理解できない患者を除いた外来通 院血液透析患者 291 名を対象に, 疲労感について聞き 取り調査を行った。また疲労感に関与する要因として 考えられる年齢, 透析年数, 透析間体重增加率, 栄養 状態，日常活動量等を調査項目に加えた，栄養状態は 血清 Alb 值で評価した.

疲労感は Fatigue Scale の中の疲労感項目 ${ }^{6}$ で, (1) 横になりたいくらい疲れる，(2)疲れた感じ，だるい感 じがする, (3)少しの運動・作業ですごく疲れる, (4)こ のごろ体が重く感じる，(5)このごろ体に力が入らな い，(6)最近の疲れ方は異常だと思う，(7)このごろ全身 がだるい，8一晚寝ても疲れがとれないの 8 項目で, 各項目についてその程度を「全くない」から「非常に 強い」の 1 5 段階で評価した.

日常生活活動は自宅での生活動作が自立しているか
どうか, 特に, 歩行（外出）がどの程度行われている かなどを検討した．透析日については透析終了後のそ の日の疲労感を調查した。透析間体重増加率は調查週 初めの 2 日空きの体重増加率を記し, 血液検查項目は 調査月のデー夕を記した。

な押, 本研究は公益財団法人浅香山病院倫理委員会 に提出し審議のうえ承認を得た。患者へは調査協力の 有無による不利益は生じないこと，デー夕は個人が特 定されないように配慮することなどを書面で説明し， 同意を得た患者を対象に調査を実施した。

\section{II. 結 果}

アンケートは 287 名（98.6\%）の患者から回答を得 た.

調查対象者は男性 193 人 (67.2\%)，女性 94 人 （32.8\%）で，男性が多かった。年齢は 30 歳代 2 人 (1\%), 40 歳代 15 人 (5\%), 50 歳代 36 人 (13\%), 60 歳代 93 人 $(32 \%), 70$ 歳代 88 人 $(31 \%), 80$ 歳代 49 人 $(17 \%), 90$ 歳代 4 人（1\%）であった.

これらは「わが国の慢性透析療法の現況 (2016 年 12 月 31 日現在)」が示す性別分布, 年齢分布と類似して いた ${ }^{8)}$.

\section{1. 疲労感の実態}

疲労感に関する設問 (1)〜8)について「全くない」「少 しある」「まあまあある」「かなりある」「非常に強い」 の程度に応じて 1 から 5 で評価した。 その分布を図 1 に示す，透析日と非透析日で回答が異なるため分けて 表示した．非透析日では種々の疲労感項目が「全くな い」が多かったのに比べて, 透析日は「少しある」「ま あまあある」が増え，「かなりある」「非常に強い」と 感じる患者もみられた．特に，「少しの運動・作業です ごく疲れる」は，非透析日は $11 \% に$ 対して，透析日は 26\%が「かなりある」「非常に強い」と感じていた，

各設問の平均值および標準偏差（ $\overline{\mathrm{x}} \pm \mathrm{SD} ）$ は, (1) 横 になりたいくらい疲れる：透析日は $2.34 \pm 1.29$, 非透 析日は $1.59 \pm 0.98 * *$ で, 以下同様に, (2) 疲れた感じ, だるい感じがする：2.38 $\pm 1.23 ， 1.66 \pm 0.97 * *$ ， (3) 少 しの運動・作業ですごく疲れる：2.34 $1.38 ， 1.79 \pm$ $1.14 * * *$ ，(4)このごろ体が重く感じる: $2.10 \pm 1.33$, $1.62 \pm 1.06 * *$ * ，(5)このごろ体に力が入らない：1.95 $1.27,1.60 \pm 1.07 * * *$ ，(6) 最近の疲れ方は異常だと思

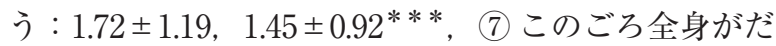
るい: $2.08 \pm 1.31 ， 1.61 \pm 1.02 * * *$ ，8一晚寝ても疲れ

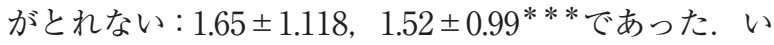
ずれも透析日と非透析日はすべての設問において有意 
透析日

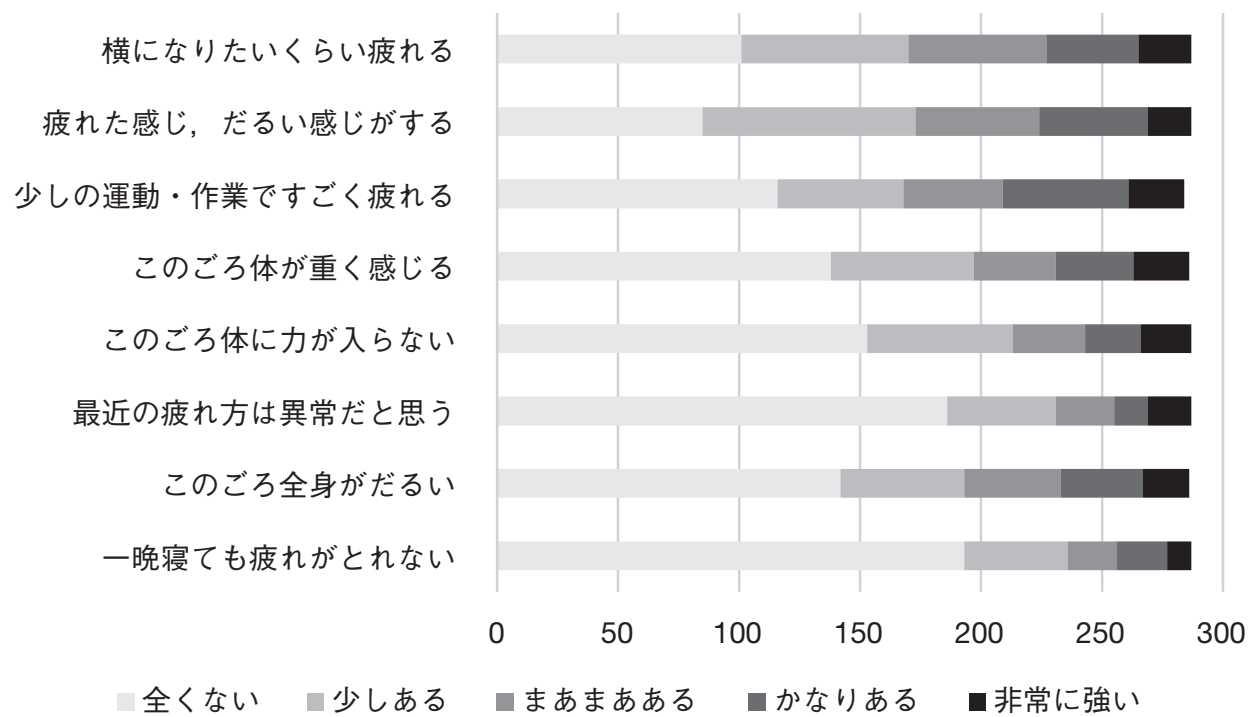

非透析日

横になりたいくらい疲れる 疲れた感じ，だるい感じがする 少しの運動・作業ですごく疲れる このごろ体が重く感じる このごろ体にカが入らない 最近の疲れ方は異常だと思う このごろ全身がだるい 一晚寝ても疲れがとれない

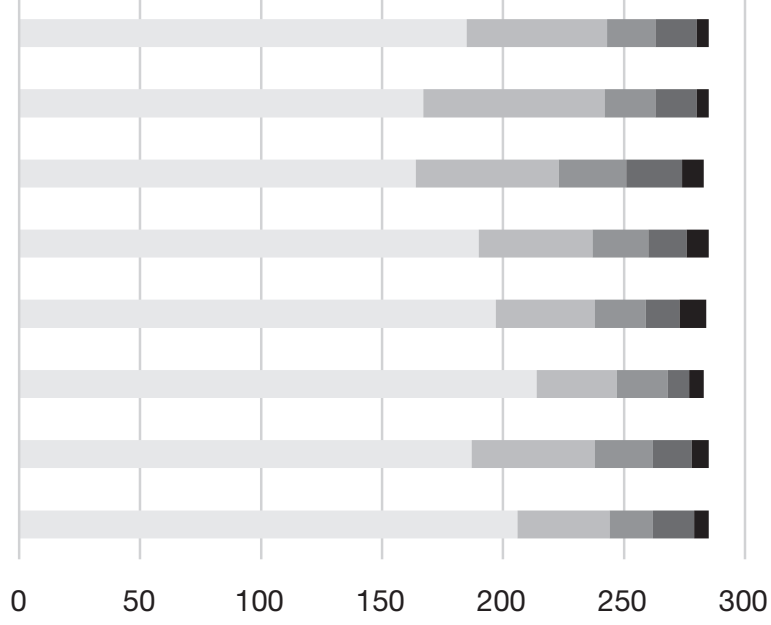

全くない、少しある、ああまあある、かなりある、非常に強い

図 1 透析患者の疲労感

差がみられた。透析日と非透析日の疲労感全体の平均 を算出すると透析日は $2.08 \pm 1.29$ で, 非透析日は $1.60 \pm 1.02 * * *$ で有意な差がみられた.

$* * * p<0.001$ (2 群間 $\mathrm{t}$ 検定 $)$

\section{2. 透析間体重増加率との関係}

体外循環による血液透析は非生理的ストレスを生 じ，その中に透析間体重増加率がある。 そこで，2 日 空きの体重増加率と疲労感の関係を検討した (図 2). まず，体重増加率を 3\%未満，3～5\%未満，5～8\%未 満, $8 \%$ 以上に分けて疲労感を比較した. 透析日の平均 值は 1.96，2.08，2.11，2.64 で体重増加が増えるにつれ て疲労感は上昇を示し, 特に $8 \%$ を超えると疲労感が
強かった。しかし, 有意な相関はなく, $3 \%$ 未満と $8 \%$ 以上の間でのみ有意差がみられた。

透析日に強く疲労感が出ていた患者も非透析日（翌 日）は軽減しており，非透析日はそれぞれ 1.61，1.65, $1.55,1.66$ と差がなかった。

\section{3. 年齢との関係}

年齢別による疲労感を図 3 に示す.

透析日においては 60 歳代が最も疲労感が強く, 60 歳代と 30〜 40 歳代, 60 歳代と 50 歳代, 60 歳以上とそ れ未満の間に有意差がみられた. 非透析日では 60 歳代 と 30〜40 歳代の間に有意差がみられた.

しかし，透析日，非透析日ともに年齢と疲労感の間 


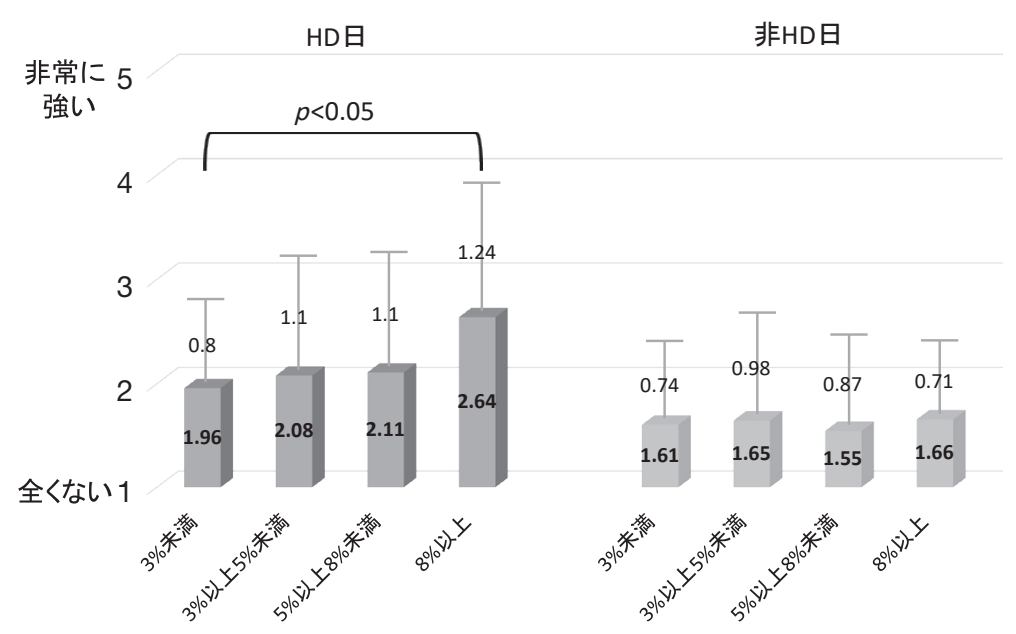

図 2 体重増加率による疲労感

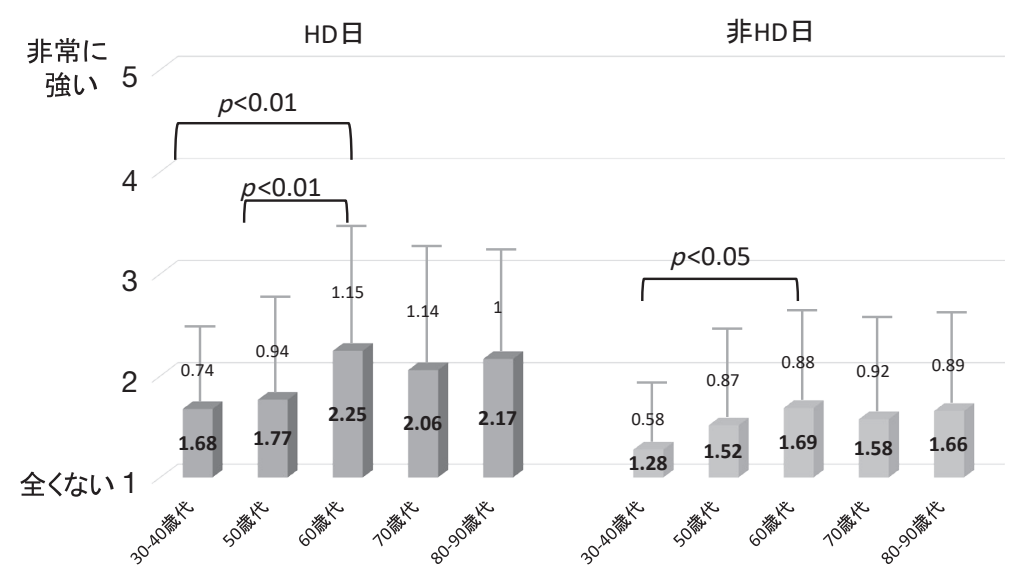

図 3 年齢別による疲労感

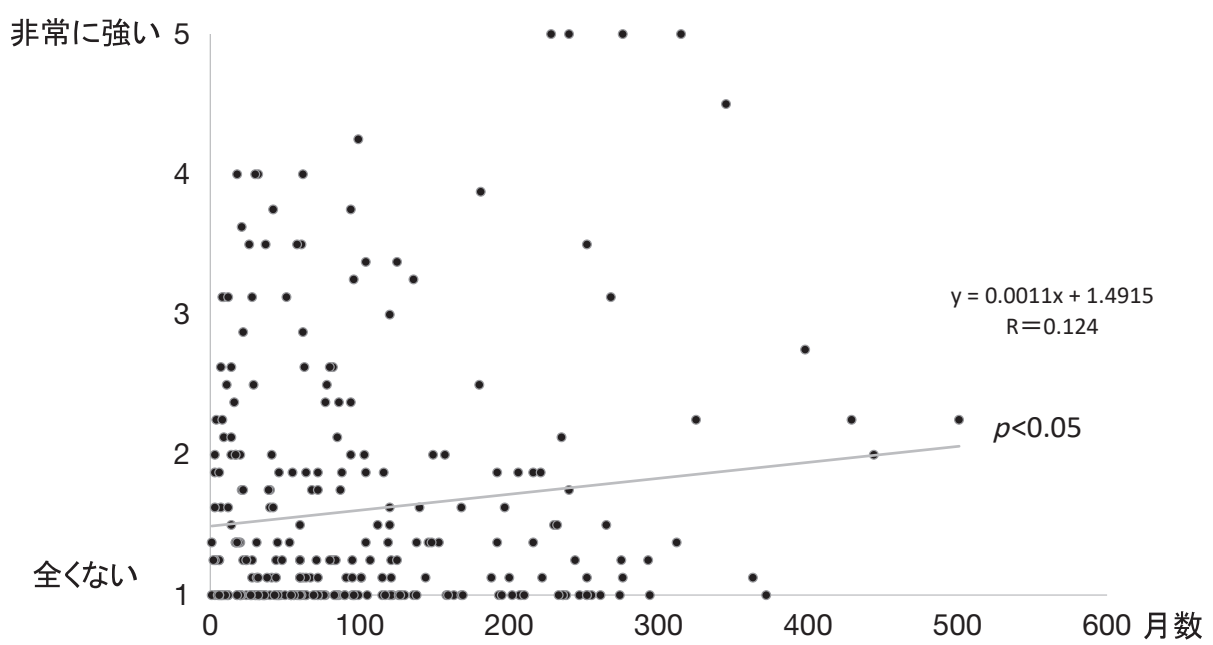

図 4 透析歴と疲労感（非 HD 日）

には有意な相関は認めなかった。

\section{4. 透析歴との関係}

透析歴（月数）と疲労感については，透析日には相 関がみられなかったが，非透析日は相関がみられた
(図 4).

\section{5. 栄養との関係}

栄養の指標としてそれぞれの患者の血清 Alb 值を用 いて比較検討した. 
HD日 非HD日

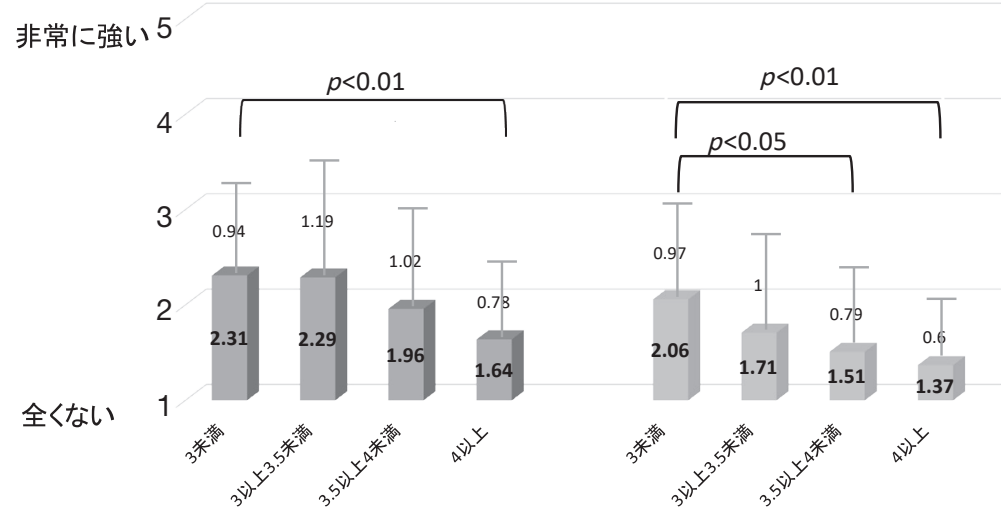

図 5 Alb 值と疲労感

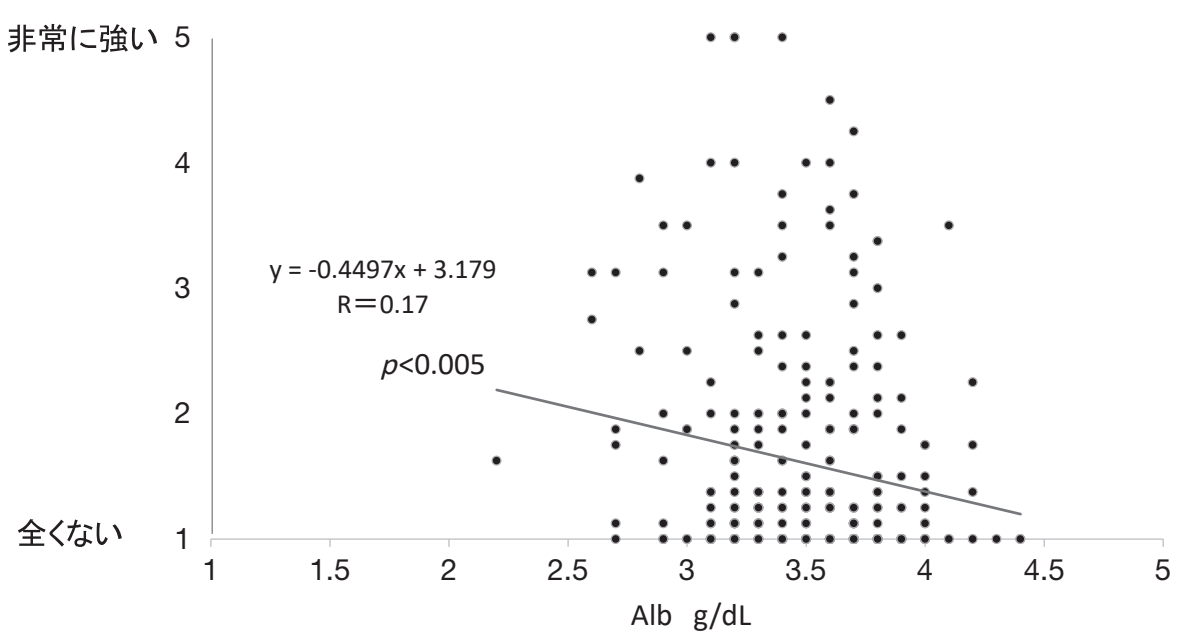

図 6 Alb 值と疲労感（非 HD 日）

Alb 值を $3 \mathrm{~g} / \mathrm{dL}$ 未満, $3 \mathrm{~g} / \mathrm{dL}$ 以上 $3.5 \mathrm{~g} / \mathrm{dL}$ 未満, $3.5 \mathrm{~g} / \mathrm{dL}$ 以上 $4 \mathrm{~g} / \mathrm{dL}$ 未満, $4 \mathrm{~g} / \mathrm{dL}$ 以上の平均值と標 準偏差を示すと, 透析日, 非透析日ともに $3 \mathrm{~g} / \mathrm{dL}$ 未満 と $4 \mathrm{~g} / \mathrm{dL}$ 以上との間に有意な差がみられた（図 5). また，透析日および非透析日のいずれにおいても， $\mathrm{Alb}$ 值と疲労感の間に負の相関がみられた（図 6).

\section{6. 日常活動量との関係}

日常生活はどの程度活動（外出・運動）しているの かを質問し, 疲労感の程度と比較した。その結果,「ほ とんど歩かない」群と「毎日 30 分以上歩く」群との間 には有意差がみられ，さらに，非透析日は「毎日 30 分 以上歩く」群と「時々歩く」群の間にも有意差がみら れた（図 7).

活動量が多い（今回のアンケート調査では「毎日外 出し 30 分以上歩く」）群は疲労感が少なかった.

\section{III. 考察}

Koyama $ら^{4)}$ は前述の 64 項目の疲労スケールを用い 慢性透析患者の疲労について多施設共同調查研究を行 い, 透析患者の疲労は一般健常人に比し有意に高く, また非透析日に比べ透析日のほうが有意に高度である ことを述べている。そして, 疲労はそれ単独で心血管 障害を予測する強力な因子であると報告している。本 研究でも透析日の疲労感は，8項目すべてにおいて非 透析日に比し有意に高度であった。 その原因は血液透 析療法そのものにあると考えられ，血液の体外循環に よる透析という非生理的ストレスで, エネルギー消費 を伴う疲労感を起こすのだと考えられる．また，非生 理的ストレスのもう一つに透析間体重増加がある。体 重増加が多いと除水速度を上げなければならない。除 水速度, 除水率が大きいほどストレスは強いと思われ るが, 疲労感と体重増加率に相関は認められなかっ 


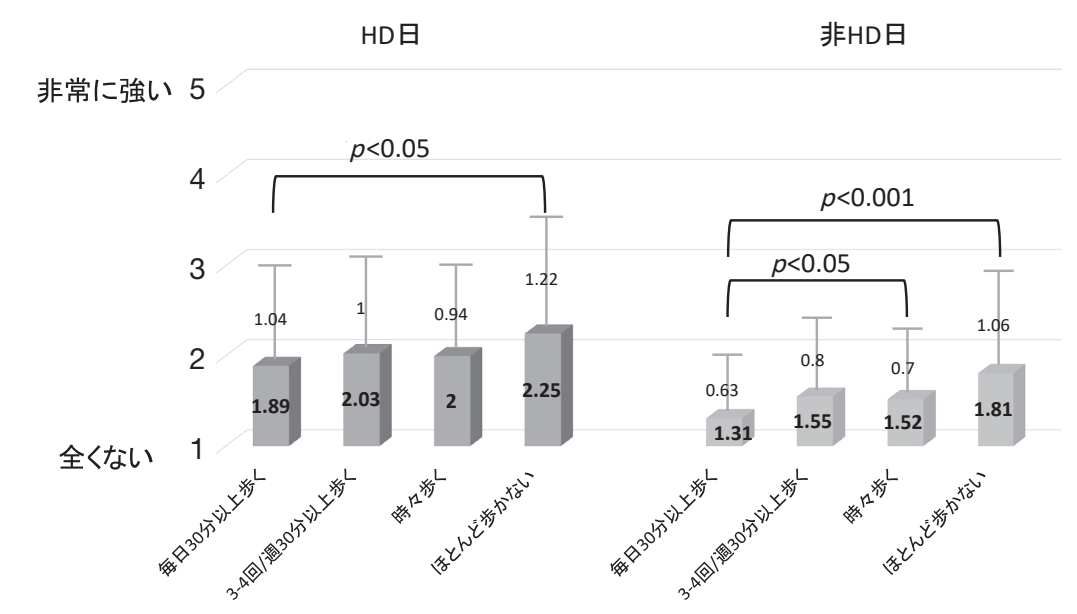

図 7 活動量（運動習慣）の差異による疲労感

た。しかし，増加率が一定 $(8 \%)$ 以上になると強い疲 労感を起こす．体重増加が少ないほど疲労感が少ない のではない，適量な食事を摂取し体重増加も適度であ る患者は，一般に自己管理ができ栄養状態が良く基礎 体力も温存されていると考えられる．栄養状態の指標 である血液蛋白量, 特に Alb 值と疲労度は透析日, 非 透析日ともに負の相関を示し，低栄養状態が疲労誘発 の強い要因となっていることが示された.

Jhamb $ら^{9)}$ は多施設共同調査研究で, アメリカ人の 透析療法導入患者の疲労／活力低下を QOL-SF36を 用いて分析し 1 年間の追跡を行っている. 透析患者の 疲労／活力低下は健常者より有意に高く, 種々の合併 症有病率, 高 CRP, 低 Alb 血症, 低クレアチニン血症 とそれぞれ有意に相関し, 疲労は予後の強い危険因子 になると報告している，特に高 $\mathrm{CRP}$, 低 $\mathrm{Alb}$ 血症は慢 性炎症を伴う低栄養状態で MIA（malnutrition（栄養 障害), inflammation (慢性炎症), atherosclerosis（動 脈硬化））症候群のリスクが高く，心循環障害への発展 リスクが高いと考えられる。低クレアチニンは筋肉量 の少なさを示しており活力低下, 易疲労につながる. また Baria $~^{10)}$, Avesani ら ${ }^{11)}$ は血液透析患者の日常 生活の身体活動能（physical activity：PA）とそれに よるエネルギー消費量 (energy expenditure：EE)を, 腕装着活動量計を用いて計測する多施設共同調査を 行っている．血液透析患者の PA (歩数)および $\mathrm{EE}$ は 年齢, 性で補正した屋外活動を殆どしない健常者に比 しても有意に低く，透析日ではさらに低下する，PA， $\mathrm{EE}$ の低下を増悪させる要因として年齢, 糖尿病, 高 いBMIであると報告している. 疲労とは休養の願望と 身体活動能力の減退状態と定義されており, PA, EE 低下度は疲労の指標とも考えることができる.

本研究では年齢と疲労感の間には透析日, 非透析日
ともに相関はみられなかったが，透析日において 60 歳 代はそれ以下に比べ疲労感が有意に強く, 非透析日に おいても 60 歳代は 30～40 歳代と比較して有意に疲労 感が強かった。 なぜ, 60 歳代の透析患者の疲労感が最 も強かったのか. 透析間体重増加率, 透析年数, Alb 值，糖尿病の有無などとの関連を検討したが偏りはみ られず，今回検討した項目ではその要因を明確にする ことはできなかった。

年齢と疲労感に相関はなかったが，透析歴と疲労感 は非透析日に相関することが認められた。透析日の疲 労は透析ストレスによる急性疲労が重なり翌日には回 復している特徴があると思われる。しかし，非透析日 の疲労は慢性疲労ととらえることができる。透析歴が 長いほど合併症の有病率, 重症度が高く栄養障害の程 度も重くなる傾向があり, 慢性的に易疲労であると考 えられる。

活動量／運動量と疲労感については透析日, 非透析 日ともに毎日外出し 30 分以上歩行する患者は有意に 疲労感が低かった. 前述の Jhambらも歩行量, 日常活 動量の多いほど活力が大きく疲労感は少ないと指摘し ている. 透析患者の日常活動量の低下は予後の悪化, 入院率, 死亡率を高めることが報告されている ${ }^{12,13)}$.

本研究では患者の高齢化にもつながる透析歴の長期 化に伴い疲労感とその程度が強くなり活力が低下する ことが示された，疲労，特に慢性疲労は活力低下 $\rightarrow$ 食 事摂取量低下 $\rightarrow$ 栄養障害 $\rightarrow$ 筋力 $\cdot$ 筋肉量低下 $\rightarrow$ 易疲労 と悪循環を招き, 結果としてサルコペニアーフレイル のリスクが高まり自立困難となり, 合併症の増悪, 生 命予後を悪化させる.

疲労, 特に慢性疲労をいかに軽減するかのケアが患 者の QOLを改善させ自立を支援することにつながる. 疲労を予防するには種々のストレスに耐える基礎体力 
の改善が必要である。そのためには，栄養状態を良好 に維持, 改善するように支援し, 黄ら ${ }^{2)}$ も指摘してい るように日常の運動量を増やし, 筋力・筋肉量を維持 させることが重要である。そして，それを実践，持続 できるような精神的サポートも不可欠であると考える.

\section{結語}

透析患者の疲労感は非透析日に比し透析日に強く表 れ，また，透析間体重増加率，透析歴，栄養状態，日 常活動量との関連がみられた。 これらより栄養状態の 維持改善と日常の活動能力の向上を推し進めていく支 援が重要である。

本研究は公益財団法人大阪腎臟バンク平成 30 年度腎疾 患研究助成金を受けた.

利益相反：申告するべきものなし.

\section{文献}

1）桑原美恵. 外来血液透析患者の主観的幸福感に関連す る要因. 第 45 回（平成 26 年度）日本看護学会論文集 慢性期看護 2015；96-9.

2）黄椀玲, 村上陽里, 川添愛, 他. 外来維持透析患者に 対する運動療法が身体機能と生活の質（QOL）に与え る影響。日腎不全看会誌 2017；19：54-7.

3）渡辺恭良. 疲労とは一疲労の統計, 疲労の科学で何を 突き止めなければならないか. 渡辺恭良編. 最新・疲 労の科学一日本発: 抗疲労. 抗過労への提言. 東京: 医歯薬出版, 2010； 5-9.

4) Koyama H, Fukuda S, Shoji T, et al. Fatigue is a pre- dictor for cardiovascular outcomes in patients undergoing hemodialysis. Clin J Am Soc Nephrol 2010; 5: 659-66.

5）日本疲労学会. 抗疲労臨床評価ガイドライン第 5 版. 平成 23 年 7 月 22 日. 3-4.

6) Fukuda S, Takashima S, Iwase M, Yamaguti K, Kuratsune H, Watanabe Y. Development and Validation of a New Fatigue Scale for Fatigued Subjects With and Without Chronic Fatigue Syndrome. In: Fatigue Science for Human Health, edited by Watanabe Y, Evengard B, Natelson BH, et al. New York, Springer 2008; 89-102.

7）小山英則, 西沢良記. 透析患者の疲労一その実態, 病 態と治療の可能性. 医学のあゆみ 2009；228：693-9.

8) https://www.jstage.jst.go.jp/article/jsdt/51/1/51_1/ _article/-char/ja/

9) Jhamb M, Argyropoulos C, Steel JL, et al. Correlates and outcomes of fatigue among incident dialysis patients. Clin J Am Soc Nephrol 2009; 4: 1779-86.

10) Baria F, Kamimura MA, Avesani CM, et al. Activityrelated energy expenditure of patients undergoing hemodialysis. J Ren Nutr 2011; 21: 226-34.

11) Avesani CM, Tolonge S, Deleaval $P$, et al. Physical activity and energy expenditure in hemodialysis patients: an international survey. Nephrol Dial Transplant 2012; 27: 2430-4.

12) Stack AG, Molony DA, Rives T, et al. Assosiation of physical activity with mortarity in the US dialysis population. Am J Kidney Dis 2005; 45: 690-701.

13) Tentori F, Elder SJ, Thumma J, et al. Physical exercise among patients in the Dialysis Outcome Practice Pattern Study (DOPPS): Correlates and associated outcome. Nephrol Dial Transplant 2010; 25: 305062. 